\title{
FACE AND POLITENESS STRATEGY APPLIED IN NANNY MCPHEE'S IN INDONESIAN SUBTITLE
}

By:

\section{Nuning Yudhi Prasetyani}

\begin{abstract}
Politeness possibly affects both in speaking and an action in an interaction. It performs the speaker has a good moral. According to Yule (2000:60), "Politeness, in an interaction, can then be defined as the means employed to show awareness of another person's face." Based on this theory, it tells how the speaker acts to conduct awareness of the other's face. Furthermore, the speaker will act carefully whenever he faces the addressee to respect his/her face, as the addressee has a higher status than the speaker. Additionally, politeness is divided into four strategies, positive politeness, on record, off record, and negative politeness. Each strategy has own way in interaction. This paper aims at investigating (1) What are the politeness strategies applied in the English and Indonesian subtitle in Nanny Mcphee and (2) What kind of translation procedures used in rendering English politeness strategies into Indonesian.
\end{abstract}

\section{Key words:}

\section{INTRODUCTION}

\section{Politeness Strategy}

In an interaction role, both the speaker and the hearer are the performer while language becomes a tool connecting those performers and engaging politeness at the same time. Leech, Geofrey N. (1983:131) argues, ...politeness concerns a relationship between two participants whom we may call self and other. In conversation, self will usually be identified with 's' speaker, and other will typically be identified with ' $h$ ' or hearer; but speakers also show politeness to the third party who may or may not be available in the certain speech situation. The label 'other' may therefore focus not only to addressees, but to people designated by the third-person pronoun. It means the speaker (self) and the hearer (other) become a target in politeness. The speaker performs politeness not only to the hearer but also to the third party; it goes to the hearer as well. Therefore, the third party has an important part during the communication although they may or may not to be present.

Politeness, depends on who stated, has few definitions but they usually have the same intention. It means, politeness focuses towards what the speaker says in a communication relating to some factors influenced the speaker utters the words. It can be concluded, politeness is the way the speaker utters the words to please the hearer's face by engaging few factors which possibly influence the way the speaker speaks. Doing face threatening act 
(FTA) during communication and engaging strategy to get what the speaker expects surely has the influence behind them.

\section{Positive Politeness}

Having the same knowledge or perception and solidarity are part of showing positive politeness. According to Brown and Levinson (1987) "When you speak to someone you may orient yourself towards that individual's positive face, and employ positive politeness (which appeals to H's desire to be liked and approved of)." The important of positive politeness is the staking of a claim for some degree of familiarity with one's interlocutor. It is thus the language of intimacy, though in certain respects an exaggerated version of intimate talk, with the exaggeration serving to mark the positive politeness that is being conveyed.

Positive politeness has an intention to avoid losing face or trying not to threaten the hearer's face since it seeks for same agreement or perception. In addition, the speaker will maintain the hearer's face to preserve his own face in front of the hearer. Besides, closeness and intimacy become signs of positive politeness and they perform friendly to the hearer, for example in giving a compliment.

\section{Off Record}

Off record actually occurs both in verbal and nonverbal, but this paper specifically concerns with the utterances. Yule, George (2000:62) says, "These, and other similar types of statement, are not directly addressed to the others. The other can act as if the statements have not even been heard. They are technically described as being off record." In other words, off record is expressing or uttering indirectly since it is difficult to shape out the meaning or message. The speaker allows the hearer to work out what he expects by himself. Moreover, not only communicating indirectly but also giving hints, being ambiguous, and making metaphor are signs of off record politeness.

\section{Negative Politeness}

Negative politeness is also known as performing an FTA with redress. In Brown and Levinson's view, positive politeness is assumed to be less polite than negative politeness. They said that negative politeness is oriented towards a hearer's negative face, which appeals to the hearer's desire not to be annoyed or put upon, to be left free to act as they choose." Based on the theory, negative face becomes a focus of negative politeness; the speaker will 
protect the hearer's negative face by giving him a freedom based on his hope. Thus, it is performed without conclusion process.

Every politeness strategy has obviously different definition. It is showed by the utterances as follow. On the other hand, some linguists state that politeness strategies possibly exist in an utterance. Yule (2000) gives an example when the speaker utters a request, 'Honey, why haven't you done the dishes yet?'. It shows that both positive politeness and negative politeness exist. The word 'honey' performs that it is positive politeness since there is an intimacy, then the later words contained by negative politeness for he says indirectly.

\section{On Record}

On record is communicating directly even though it is unpleasant feeling which is part of positive politeness. Yule, George (2000:63) says, "The most direct approach, using imperative forms is bald on record." In addition, Yule, George (2000:63) says, "These bald on record forms may be followed by expression like 'please' and 'would you?' which serve to soften the demand and are called mitigating devices." The later cites that the utterances contained bald on record is more direct without bearing in mind of losing his face while the former means, the speaker might not want to appear as a dictator so he uses those words to lessen intimidation On the other side, a linguist notes about type of on record, bald on record.

\section{Pragmatics Equivalence}

Translation activity has the main purpose that is to find equivalence in meaning. Here, the equivalence is focused on the meaning aspect, rather than the grammatical. Mona Baker (1992) differs equivalence into five categories, namely: equivalence at word level, equivalence above word level, grammatical equivalence, textual equivalence, and pragmatic equivalence. Nida (1969: 12) said that "translation consists in reproducing in the receptor language the closest natural equivalence of the source language message, first in term of meaning and secondly in terms of style". The statement shows how good translation can be achieved, i.e. by producing an equivalence message that is as close and natural as possible with the Source Text (ST). Equivalence is not the same as sameness. Basnett-McGuire proposed that "equivalence in translation should not be approached as a search for sameness since sameness cannot even exist between two TL versions of the same text" (1991: 29). So, that is why translators sometimes have different point of view in determining the concept of equivalence. 
Ardiana also stated that in pragmatics, the meaning of a text is interpreted based on context. This context, according to Baker (1992: 238), is closely related to the implicate problem in pragmatics "the context in which an utterance occurs determines the range of implicates that may sensibly be derived from it". For this reason, equivalence in meaning, which has to be transferred into the Target Text (TT), can be realized by applying various translation strategies to produce a 'make sense' translation for the readers. Make sense, in this respect, means that the TT must sound natural for the TT readers because it is appropriate to their culture, concept, and language structure as well. In pragmatics, meaning is influenced by the participants involved in the communication situation. In relation to verbal text, Kussmaul in Ardiana (2009) added that "social meanings are determined to a large extent by the paralinguistic and non-linguistic conditions under which the utterances take place. Thus tone of voice, facial expression and gestures are important clues for getting at the social meaning behind the words". The statement is very relevant in the searching of pragmatic meaning of utterances in a movie. The meaning of a certain utterance, besides searched from linguistic factor, can also be analyzed by considering the speaker ${ }^{\text {ee }}$ tone (high, fast, loudly, etc.), gesture, facial expression, and action.

Thus, in translating politeness, Brown and Levinson in Hatim and Mason's 'Politeness in Screen Translation' (2000: 433) said that present evidence from unrelated social and linguistic culture to show that, whereas the linguistic realization of politeness varies considerably, there is remarkable uniformity of underlying strategy, which might suggest that politeness is a universal feature of natural language communication. Furthermore, they said that from a translation point of view, what this might suggest is that the dynamics of politeness can be relayed trans-culturally but will require a degree of linguistic modification at the level of texture.

\section{Subtitling Procedures}

In many ways, subtitling procedure has the same purpose as in translation procedure since it deals with rendering the meaning. Some scholars may use the word 'procedure' and 'technique' to refer the same perspective dealing with how to translate or render the meaning in lingual level (word, phrase, clause and sentence). Here, I want to use Newmark's procedures (1998: 81-91) in translating these sentences in this film subtitle.

1. Literal

The SL grammatical constructions are converted to their nearest TL equivalents but lexical words are again translated singly, out of context. 


\section{Transference}

This term has the same meaning as 'borrowing' (a word or expression is taken directly from another language).

3. Naturalization

This procedure succeeds transference and adapts the SL word first to the normal pronunciation then to the normal morphology.

4. Cultural equivalent

This is an approximate translation where a SL cultural word is translated by a TL cultural word. It has a greater impact than culturally neutral terms.

5. Functional equivalent

This procedure requires the use of a culture-free word sometimes with a new specific term; it therefore neutralizes or generalizes the SL word. This procedure, which is a cultural componential analysis, is the most accurate way of translating, for example deculturalising a cultural word.

6. Descriptive equivalent

In translation, description sometimes has to be weighed against function. Description and function are essential elements in explanation and therefore in translation.

7. Synonymy

This procedure is used for a SL word where there is no clear one-to-one equivalent, and the word is not important in the text, in particular for adjective or adverbs of quality (which in principle are 'outside' the grammar and less important than other components of a sentence). A synonym is only appropriate where literal translation is not possible and because the word is not important enough for componential analysis.

8. Shift or transposition

A 'shift' (Catford's term) or 'transposition' (Vinay and Darbelnet) is a translation procedure involving a change in the grammar fro SL to TL.

9. Modulation

It is a superordinate term covering almost everything beyond literal translation. As Newmark agrees with Vinay and Darbenelt's opinion on modulation 'a variation through a change of viewpoint, of perspective and very often a category of thought.

10. Recognized translation

The translator can gloss the term and while in doing so, indirectly show the disagreement with this official version. 


\section{Translation label}

This is a provisional translation, usually of a new institutional term which should be made inverted commas, which can later be discretely withdrawn. It can be done through literal translation.

12. Compensation

This is said to occur when loss of meaning, sound-effect, metaphor or pragmatic effect in one part of a sentence is compensated in another part, or in contiguous sentence.

13. Componential analysis

This is the splitting up of a lexical unit into its sense component, often one-to-two,-three, or-four translations.

14. Reduction and expansion

There is one shift which a translator likes to bear in mind, particularly in poorly written texts.

15. Paraphrase

This is an amplification or explanation of the meaning of a segment of a text. It is used in an 'anonymous' text when it is poorly written, or has important implication or omission.

16. Other procedures

According to Newmark, Vinay and Darbenelt also give: (1) Equivalence, implying approximate equivalence accounting for the same situation in different terms. They are simply referring to notices, familiar alternatives, phrases and idioms-in other words, different ways of rendering the clichés and standard aspects of language, (2) Adaptation, use of recognized equivalent between two situations. This is a matter of cultural equivalence.

17. Couplets

Couplets, triplets, quadruplets combine two, three or four of the above- mentioned procedures respectively for dealing with a single problem. They are particularly common for cultural words, if transference is combined with a functional or a cultural equivalent.

\section{Plot}

19th century England, widowed undertaker Cedric Brown (Colin Firth) has seven children: Simon (Thomas Sangster), Tora (Eliza Bennett), Lily (Jennifer Rae Daykin), Eric (Raphal Coleman), Sebastian (Samuel Honywood), Chrissy (Holly Gibbs) and baby Aggie (Hebe and Zinnia Barnes). He loves his children very much, but spends little time with them, unable to handle raising them all on his own after their mother died. The children have had a 
series of seventeen nannies, whom they systematically drive out; it is a point of pride for them to get rid of each nanny as fast as possible. They also terrorize the cook, Mrs. Blatherwick (Imelda Staunton) but are cared for and loved by Evangeline (Kelly Macdonald) the young scullery maid.

Cedric attempts to hire another nanny from the agency that sent the past seventeen nannies, but the agency refuses him, as the children have sent the past nannies away, terrorized. Desperate to find another nanny, Cedric heeds the advice of a mysterious voice from the house, which says, "the person you need is Nanny McPhee." After a series of mysterious events, an unusual and hideous woman named Nanny McPhee (Emma Thompson) arrives at Brown home, introducing herself as a "government nanny."

Nanny McPhee always taps her magic stick when she manages the naughty children. She, finally, become a good friend and savior for the children. Now that the children have learned all of Nanny McPhee's lessons, she has been transformed from the heavyset hag they first met into a beautiful young woman. As the wedding ceremony commences, Nanny McPhee is seen in the final frames, her silhouette walking into the horizon, with her voiceover reiterating her earlier declaration that "When you need me, but do not want me, then I must stay. When you want me, but no longer need me, then I have to go."

\section{RESEARCH METHOD}

A qualitative method is applied in this study. This method focuses on words rather than numbers (Sutopo, 2006). The data are taken from the utterances among characters in the Nanny Mcphee's movie. The focus of this study is on finding utterances containing politeness strategy and what translation procedures are applied in rendering the meaning.

\section{III.DATA}

Positive and Negative Politeness in Nanny Mc Phee's movie

Indonesian Subtitle

1 Evangeline : Mr Brown, are you all Evangeline: Tn. Brown, anda right?

baik-baik saja?

Mr. Brown : I'm perfectly all right. Tn. Brown: aku baik-baik saja.

Evangeline, could you let Cook know Evangeline, bisa beritahu koki

that the new nanny has had to leave bahwa pengasuh barunya harus 
and I'm off to the agency to find a new pergi dan aku akan ke agen one?

untuk mencari penggantinya?

This is the conversation between Mr. Brown and Evangeline (host and scullery maid). The utterance that they use in this conversation refers to negative politeness with bald on record strategy bald on record since there are power and distance between these two people. The translation procedure used in this sentence is literal. It seems that in the SL, the speaker gives the hearer the chance to choose the 'yes' or 'no' answer.

2 Mr. Brown : Well, you seem intent Tn. Brown: agaknya, kalian on distressing me... Er...don't do that, berniat membuat ayah stress. darling, please. That's my sore bit. You Er...jangan begitu, sayang itu seem intent on distressing me, so I'm bagian yang sakit. Kalian berniat going to distress you. You are to...to go membuat ayah stress jadi ayah to bed immediately. akan buat kalian stress. kalian harus ... segera pergi tidur

$\begin{array}{lll}\text { Sebastian } & \text { : Before supper? } & \text { Sebastian: sebelum makan malam? } \\ \text { Mr. Brown } & \text { : Without supper. } & \text { Tn. Brown: tanpa makan malam } \\ \text { Sebastian } & : \text { Did he say without } & \text { Sebastian: Ia bilang tanpa makan } \\ \text { supper? } & & \text { malam? }\end{array}$

This is the conversation between Mr. Brown and his naughty children. Mr. Brown felt disappointed and distressed when facing the unmanageable children. Here, I found hedges (Well, Er..) referring to negative politeness with on record strategy because the speaker can minimise the imposition by making it smaller than it is, or by adding devices such as hedges that mitigate the imposition, such as 'if possible', 'in a way', , I wonder..and Er..., I think you may be late... (Cutting, 2008: 45). This is literal translation.

3 Evangeline: Quiet! You're driving your Evangeline: Diam! kalian buat poor father to distraction. Stop it. ayah kalian terganggu. Hentikan! Evangeline (scullery maid) orders the children to be quiet since they make any noise and she almost failed to make them to stay calm. Evangeline uses positive politeness with bald on record strategy because of the emergency situation that 
refers to the use of direct commands regardless of who is being addressed...(Yule, 1996: 64). Literal translation with deletion of the phrase 'poor father' is applied but it does not distort the meaning.

4 Sebastian: I really am hungry, Sebastian: Aku lapar sekali, Evangeline. Could you maybe bring me Evangeline. bisa bawakan aku some secret toast and jam? All right, roti panggang dan selai? baiklah, forget the jam. Just some secret toast. selainya tak usah. roti panggang saja.

This is Sebastian's utterance when he and their brothers and sisters are punished by her father (Mr. Brown) for not allowed of having dinner. So, he begs to Evangeline to bring some toasts and jam. This conversation uses negative politeness with bald on record strategy. The translation procedure used in this conversation is literal and the translation is accurate.

5 Evangeline : Shall I plump the cushion Evangeline:

Perlukah on Mrs Brown's chair? I know you like kugemburkan bantal di kursi $N y$. to plump it yourself sometimes. Brown? Aku tahu terkadang kau Mr. Brown : Oh, no, that's...that's all suka melakukannya sendiri right. You plump away, Evangeline. Tn. Brown: Tak apa ... silakan Thank you. saja...trimakasih

Evangeline : I was wondering if $I$ Evangeline: $A k u$ ingin tahu apa might make master Sebastian a piece of boleh membuatkan roti panggang toast. untuk Tuan Sebastian?

Mr. Brown : Yes, I should think... Tn. Brown: ya, kurasa....tidak, Er...no, under no circumstances. No. tidak boleh

Evangeline : I could do it secret-like. Evangeline: bisa kulakukan diamMr. Brown : No, they'll hear him diam

chewing and then we're done for. No, Tn. Brown: tidak, mereka akan they get nothing. mendengarnya mengunyah dan Evangeline: Righto, Mr Brown. kita berantakan Evangeline: baik, Tn. Brown 
In this utterance 'Shall I plump the cushion on Mrs Brown's chair? And the translation 'Perlukah kugemburkan bantal di kursi Ny. Brown?' and I was wondering if I might make master Sebastian a piece of toast and the translation 'Aku ingin tahu apa boleh membuatkan roti panggang untuk Tuan Sebastian? the speaker uses negative politeness with off record strategy and the translation procedure is literal. Here, Evangeline pay attention to negative face by demonstrating the distance between her and her master, Mr. Brown. She tries to avoid imposing or presuming, and to give the hearer options. She can avoid imposing by emphasizing the importance of Mr. Brown's time and concerns, using apology and hesitation, or a question giving him opportunity to say 'no'.

6 Simon: What on earth are you doing?

Tora: Getting ready for bed.What she Tora: bersiap untuk tidur. yang told us to do.

Simon: Since when did we do what Simon: Sejak kapan kita lakukan we're told?

Tora: Since we nearly got Cook blown up and Aggy boiled.

Simon: May I just remind you of Aggy

something? We got rid of the last 17 Simon: boleh kuingatkan sesuatu? nannies. We're getting rid of this one kita sudah singkirkan 17 too.

\section{yang disuruh?}

Tora: sejak kita hampir meledakkan koki dan merebus pengasuh. kita akan singkirkan juga yang ini

These two conversations show that they are annoyed by the presence of Nanny Mcphee who always orders and asks something that they do not want to do. The utterance 'What on earth are you doing? And the translation 'apa-apan kalian?' shows positive politeness with off record strategy. The translation procedure is equivalence since 'What on earth are you doing? become 'apa-apan kalian?' shows that implying approximate equivalence, accounting for the same situation in different term because it refers to idiomatic expression. And in 'Since when did we do what we're told? Translated literally into 'Sejak kapan kita lakukan yang 
disuruh? Refers to positive politeness with on record strategy since they are brothers and sister who have a good common background and goal, as Brown and Levinson (1987) says that speaker can do that by attending to the hearer's interest, wants and needs.

7 Mr. Brown: You don't happen to know Tn. Brown: apa kalian kebetulan if... if she ever...ever, erm...remarried? tahu bahwa dia pernah You know, number four? ...menikah lagi? yang keempat?

Mr. Jowls (Mr. Brown's cowoker): Mr Tn. Jowls: Tn. Brown, kau tak

Brown, you're not thinking what I berpikir yang kupikir kau

think you're thinking, are you, Mr pikirkan, kan, Tn. Brown?

Brown?

Mr. Brown: Good grief, no! No, no. No. Tn. Brown: astaga, tidak... tidak... No. tidak mana mungkin

These conversations between Mr. Brown and his cowoker, Mr. Jowls about Mr. Brown's intention on marrying Mrs. Selma (a flirtatious widower). Here are applied negative politeness with on record strategy signed by hedges (.....if... if she ever...ever, erm...remarried?) and tagging (what I think you're thinking, are you, Mr Brown?). Literal procedure of translation is applied since it does not need any cultural point of view in rendering the meaning.

8 Nanny Mcphee : Evangeline, please ask Nanny Mcphee: Evangeline, Cook to make the children scrambled tolong bilang tukang masak eggs on toast. I'm sure they'd like supper untuk membuatkan anak-anak now they're feeling better. orak-arik telur di roti panggang. Evangeline : I'll do it myself, Nanny Aku yakin mereka akan makan McPhee. malam karena mereka sudah sembuh Evangeline: Akan aku kerjakan sendiri, pengasuh Mcphee

The sentence 'Evangeline, please ask Cook to make the children scrambled eggs on toast' translated into 'Evangeline, please ask Cook to make the children 
scrambled eggs on toast' refers to literal translation. This is the conversation between nanny Mcphee and Evangeline while they are talking about what is the good meal for the children as they are recovering from a day-sick. This refers to positive politeness with on record strategy since Nanny Mcphee wants to mitigate her utterance to Evangeline by soften the demand in saying 'please'.

\section{IV.CONCLUSION}

The aims of the study are to find out the type of politeness strategy and the translation procedure used in translating the utterances. The findings show that almost all of the utterances are translated using literal techniques and the politeness strategies that become the most used by the characters are negative politeness strategy with on record because some utterances are applied by children to their parents or someone who take a good care of them (their nanny) besides it also show the background of the story which refers to a noble family, so they must behave and have a polite utterance.

\section{REFERENCES}

Baker, Mona. (1992). In other Words. Routlegde. London and New York

Brown, P and Levinson. (1987). Politeness: Some Universal in Language Usage. Great Britain. Cambridge University Press.

Cutting, John. (2008). Pragmatics and Discourse. A Resource Book for students. $2^{\text {nd }}$ edition. Routledge, Great Britain.

Leech, G.N. (1983). Principles of Pragmatics. Great Britain. Cambridge University Press

Nanny Mcphee's script (English version). www.downloadfilmscript.englishversion.com

Nanny Mcphee's script (Indonesian subtitle's version). www.downloadfilmscript/indonesianversion.com

Newmark, Peter. (1998). A Textbook of Translation. Prentice Hall Europe 
Nida, A. Eugene. (2001). Context in Translating. John Bejamins Publishing Company. Amsterdam

Nuraeni, Ardiana. (2011), The Subtitles Of Speech Act Of Complaint In The Movie Bad Boys II Presented On Television And On VCD: Which One Is Better?. Paper. UNS University

Sutopo. H.B. (2006). Metodologi Penelitian Kualitatif. UNS Press

Yule, George. (1996). Pragmatics. Oxford. Oxford University Press 